University for Business and Technology in Kosovo

UBT Knowledge Center

Oct 28th, 9:00 AM - Oct 30th, 5:00 PM

\title{
Daily migration as indicator to defining Functional Urban Region - case of Prishtina
}

\author{
Elvida Pallaska \\ University for Business and Technology, elvida.pallaska@ubt-uni.net
}

Follow this and additional works at: https://knowledgecenter.ubt-uni.net/conference

Part of the Architecture Commons

\footnotetext{
Recommended Citation

Pallaska, Elvida, "Daily migration as indicator to defining Functional Urban Region - case of Prishtina" (2016). UBT International Conference. 76.

https://knowledgecenter.ubt-uni.net/conference/2016/all-events/76

This Event is brought to you for free and open access by the Publication and Journals at UBT Knowledge Center. It has been accepted for inclusion in UBT International Conference by an authorized administrator of UBT Knowledge Center. For more information, please contact knowledge.center@ubt-uni.net.
} 


\title{
Daily migration as indicator to defining Functional Urban Region - case of Prishtina
}

\author{
Elvida Pallaska \\ UBT - Higher Education Institution, Lagjja Kalabria, 10000 p.n., \\ Prishtine, Kosovo \\ elvida.pallaska@ubt-uni.net
}

\begin{abstract}
Cities and metropolitan areas are major contributors to national economies and play a key role as nodes in global markets. Moreover, at a time of deepening globalisation and increasing international competition for investment, metropolitan regions have become the targets of a wide range of public interventions.

Evaluation of existing and future potentials, role and function of Prishtina as capital city vs its region- neighboring cities (Fushw Kosove, Kastriot, Lipjan and Podujeve), with the capital infrastructure resources, functions and management, classification and definition of its commuting zone from the perspective of its daily migration as per OECD criteria.

Definition of the Functional Urban Region is of big importance to the city of Prishtina, its regional future spatial development, planning and management, data track keeping, measurements and exchange with other national/regional statistical offices, important as to comparison with other Functional Urban Region in close region and with any city within the European Community.
\end{abstract}

Keywords: Urbanisation, Migration, Functional Urban Zone, Metropolitan Urban Region, Urban sustainability, Sustainable Urban Transport, Urban mobility, Creative Cities;

\section{Introduction}

The main aim of the research is the definition of the Functional Urban Region of Prishtina, city and its neighboring cities (Fushe Kosove, Kastriot, Lipjan and Podujeve), as for the definition of reccomendation to future development policies and strategies top regional development planning. The definition of the Metropolitan region of Prishtina would be according to the evaluation of existing potentials, its daily functions and functioning trends to development, its daily commuting trends; Prishtina future potential role and function vs its region- in the context of spatial planning and management, capital infrastructure resource planning and management; classification and definition of its commuting zone from the perspective of its daily migration as per OECD criteria. Definition of the Metropolitan Urban region is of big importance to the city of Prishtina, its regional future spatial development, planning and management, data track keeping, measurements and exchange with other national/regional statistical offices, important as to comparison with other Metropolitan Urban Regions in close region and with any city within the European Community. The hypothesis to this research is:

"Prishtina city could be and is necessary to be defined as Prishtina Metropolitan Urban Region, according to the high percentage of daily migration from neighboring cities, (Fushë Kosovw, Lipjan, Kastriot and Podujevë), its functional role and economic importance vs its neighboring cities, its competitiveness and future role toward knowledge - based development, that means sustainable development of the region. By its commuting zone, could be defined Functional Urban Zone of Prishtina, that might function more efficiently, in more competitive way, if being taken in 
time and quality manner, measures in planning, policy compilation, implementation, governance and cooperation with other urban regions."

The first part of analyzes to this study are as follows:

- Analyses of Pristina and its region (Metropolitan area - BLUE PORT with neighboring cities) in geografical, infrastructural context and role (Prishtina International Airport, Central Railway Station, Electrical Powerplant) as for the definition of Functional Urban Area;

- Analyses of Prishtina and its region according to the Urban Development Plans, as well as per National Spatial Plan of Kosovo - NSP of Kosova 2010 - 2025 +;

- Analyses of current trends of daily migration into the City of Prishtina, from its neighboring municipalities- region, workers /day as per Staistical Data in Kosovo (ESK, 2014) and its comparison of the data of migration in "Prishtina metropolitan region" with other OECD/EU cities/regions data and trends as per the definition to Urban Metropolitan Region;

With the synthesis of the analysis, results will be summarized in terms of defining the conclusions and recommendations for urban/regional policy development needed to support the intentional development toward Metropolisation of Prishtina Region, competitiveness and internationalisation of it;

\section{Research method}

The research is a qualitative and exploratory study, based on qualitative data containing primary and secondary data on the city's current profile and the strategies on national and local level of Kosova, Prishtina and neighboring cities.

The desk part of the research has been conducted in terms of literature review, theoretical background and intl experiences of succesful cities in EU becoming or functioning as City regions. At the second stage were conducted: A) Analyses of Prishtina and the region potentials and trends, role and functions toward definition of Metropolitan Urban Region; B) Analyses of spatial plans and strategies, expectations and actions toward definition of Metropolitan Urban Region, in spatial development perspective, metropolitan and polycentric development; C) Analyses of the statistics of daily migration as per last census of 2011, in the context of the Metroplitan Urban region of Prishtina and the criteria of OECD.

\section{Literature review}

Its is the fact that "Cities are one of the most relevant places to observe, understand and influence changes in all fields of economy and the society" (Future, 2005) though there is a direct relationship between urbanization, metropolisation and competitiveness (Giffinger, 2011), involving development of policentricity as functional metropolitan agglomeration in an urbanized world. (POLYCE, 2013)

Cities are part of a network of different forms of relations, where competition becomes decisive, though looking at the development perspectives of the urban system in Europe - and Central Europe more specifically - the reasons for an increasingly competitive context can easily be found. The allocation of investments and economic activities across different types of cities follows distinct characteristics on the basis of comparative advantages that cities are able to provide. (ESPON, 2013). 
According to the OECD definition of the EU, identified 828 cities with urban center with at least 50,000 inhabitants. Half of these cities are relatively small (between 50,000 to 100,000 inhabitants), while only London and Paris are considered global cities that accommodate $40 \%$ of the EU population. Each city is part of its area of migration or migration area covering more polycentric cities. These areas along accommodate migratory areas together (larger urban areas) $60 \%$ of the EU population. Since 1986, the aim of territorial cohesion policy was to strengthen economic and social cohesion.

The Treaty of Lisbon and high strategy of the EU (Europe 2020), we talk about a new third dimension: territorial cohesion. This topic has been discussed since the early '90s as with any state inkuadrohej EU, whose territory was sensitive to new developments in the EU, while developments within a given territory of a city.

In the European Union's regional policy, outlined in the strategic document (Europe 2020 strategy) following main goals for cities - regions of the European Union countries and countries in their aim to EU integration: i)- Management concentration- The population and development, taking into account the need for increased innovation and production in cities, with ingredients demonstration pollution management and social divisions;ii)- Better connected territories - People should be able and free to live where they want, with access to public services, transport, efficient, reliable energy network and the Internet throughout the territory; iii)- Development of cooperation due to the effect of climate change and traffic challenges that do not stop at administrative borders, creating new forms of cooperation needed between cities, regions and countries.

In general, territorial cohesion policy, reformed for the period from 2014 - 2020, will be taken closer towards 370 billion euros, to invest in Europeans regions, cities and real economies. It will be an investment vehicle of the EU to achieve the EU's goals: creating jobs, supporting climate change and energy dependence, reduce poverty and social divisions. (OECD, 2011)

\subsection{Intl expriences of cities-Metropolitan urban regions}

CITY REGION OF AACHEN- Aachen has about 250,000 inhabitants and unlike other cities Ruhr area, Aachen population is growing. Region consists of the subregions Aachen Aachen, Dueren, Euskirchen, Heinsberg and the city of Aachen's. In this region live more than 1.3 million inhabitants. (2007). In administrative terms, the five subregions of the Aachen region are part of the Federal State of North Rhine -Westphalia (NRW) and to be more specific, part of the district of Cologne (one of the 5 districts of NRW). For more, "Region Aachen" as such does not exist in political and administrative terms, anyway, many of the public's institutions operate are located in Aachen region, among them and Aachen Chamber of Commerce (IHK) as well as the Agency development of Aachen (AGIT). Aachen is truly a city of students - 40,000 out of 250,000 inhabitants are students. In comparison with other cities of the Ruhr region, the population of Aachen is growing.

CITY REGION OF LJUBLJANA- As an example of a city - the region for comparison in this study have Ljubljana region, this region which including the capital of Ljubljana, brings together 26 local authorities with around 500,000 inhabitants, as most populated / densely Slovenia.

\section{Analyses of potentials of Prishtina with its neighboring cities toward being defined as Fuctional Urban Region}

Prishtina is relatively small city in comparison with other capitals /knowledge centres in the region, but hence is the capital city that serves as centre of administration, governmental head quarters, foreign liaison offices and embassies, higher education, cultural events etc., requiring to a certain extent to fulfil the conditionality called urban scale. Regarding new urban developments of Prishtina, different scenarios were foreseen. In every scenario, the inner city is of high strategic 
Book of Proceedings

International Conference on Architecture and Spatial Planning

value, serving as centre of functions where trade, offices, public administration, cultural and leisure facilities as well as complementary dwelling units would be located.

In the XX century, Prishtina developed into a "modern" European city, with its more than 20000 inhabitants in core city while cca 250000 inhabitants, in the municipality of Prishtina. In total MUR of Prishtina counts cca 406 ooo inhabitants.

Accessibility - Prishtina is the main Kosova transport nexus with the only international airport, the high way Tirana Prishtina Nish, and ongoing and in construction highway, Prishtina- Nish. The main railway line Belgrade - Skopje and almost all important roads passing through the city of Prishtina. Transport Intl corridors are bypassing Kosova/Prishtina though. ANP - International Airport of Prishtina, HK - Main Train Station and Powerplant are located in three different neighboring cities, but managed daily by Prishtina city, that causes primary need to function as one urban region in close cooperation between each other.
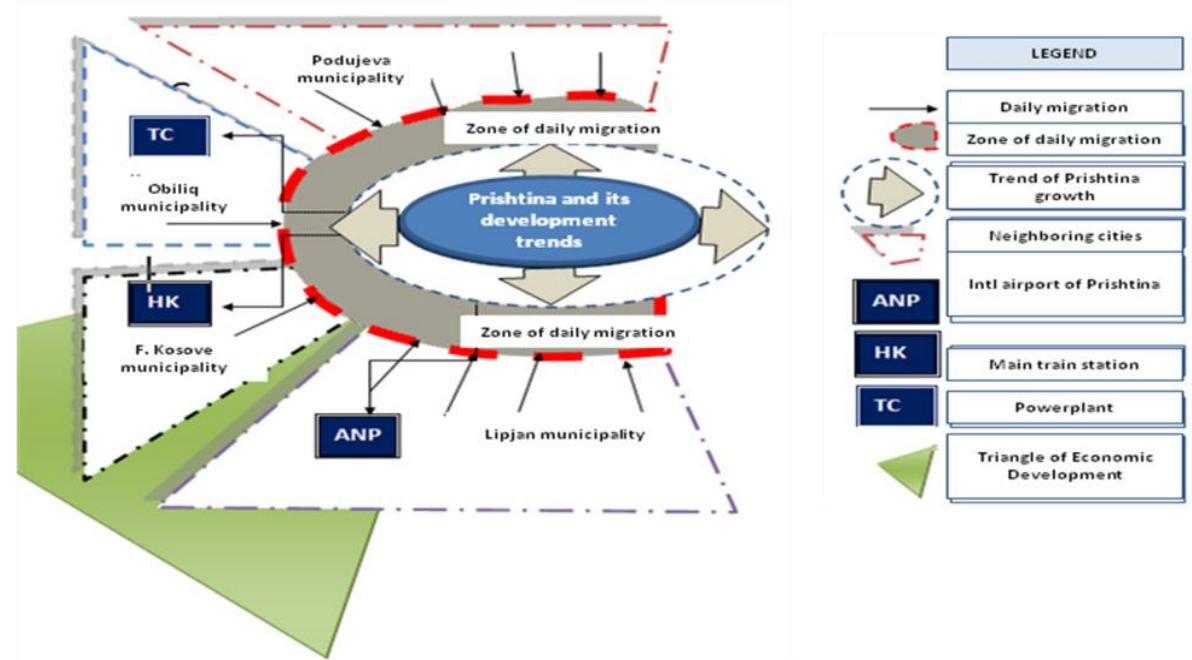

Fig. 1. Scheme of the context of urban region of Prishtina

\subsection{Analyses of Prishtina and its region according to the Urban Development Plans}

This chapter presents empirical part of research analysis of Prishtina and neighboring cities expectations deriving from development plans, national and urban development plans. Would be elaborated and analysed Prishtina and four other cities plans and development orientations. Analysis would be analysed as per the main objective to this research, whether are supportive to the regionalization of Prishtina with the cities around, unbundling it to more detailed actions that would support the main goal of metropolisation of Prishtina region.

SPATIAL PLAN OF KOSOVA 2010 - 2025 + - Prishtina and its region (four other cities around) is foreseen to be the generator of national income, as per National Spatial Plan of Kosova $2010-$ 2025+. By this, it is called the Blue Port of Kosova, region that has in its core, the city of Prishtina, as the holder of the role and importance, meaning the gate to the outside world in every aspect of it. 


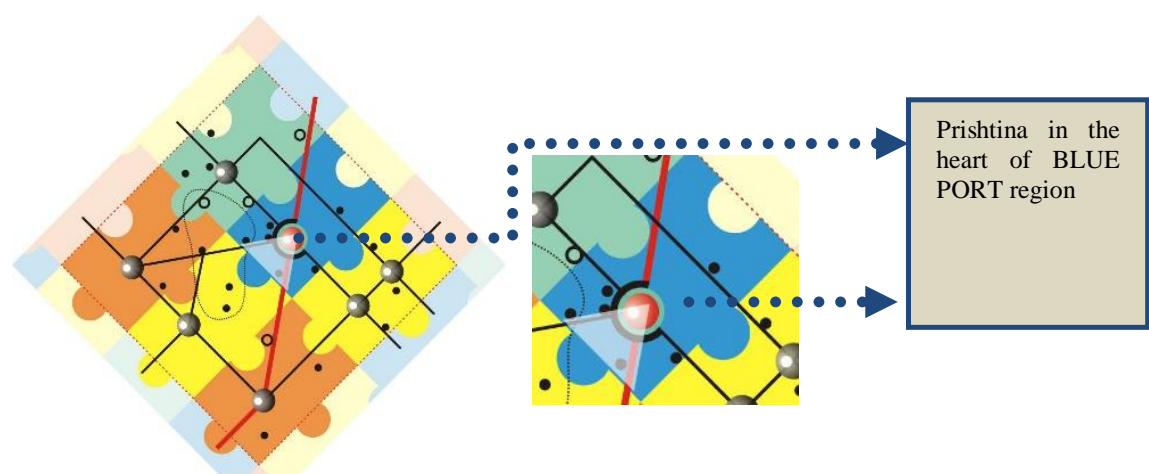

Fig. 2 Regional distribution of Kosova as per potentials and development orientations (SPK 2010)

\subsection{Analyses of daily migration to the city of Prishtina as per OECD}

In this part of the research would be analysed, the city of Prishtina and four neighboring cities (Lipjan, Fushë Kosovë, Obiliq and Podujevë) as Functional Zone5859, as per OECD. Identification of the wider urban area of Pristina, serves for comparability with other functional areas of the European urban world, functional urban areas of Europe, based on regional statistical data.

According to the population census of 2011 it appears that the municipality of Prishtina has 198,897 inhabitants, while the urban region to this study, consisting of five municipalities including Pristina has over 405,899 inhabitants.
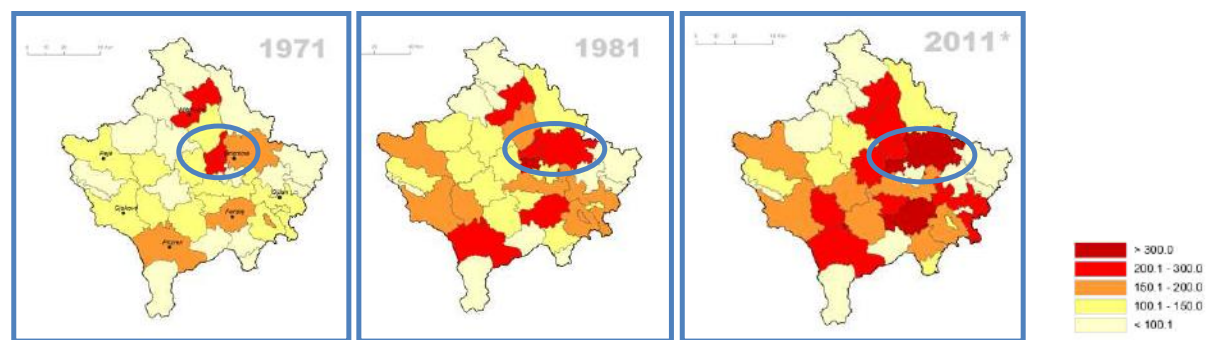

Fig. 3. The average density of population by regions in Kosovo (ESK, 2011)

In the figure above is shown the trend of densification the Pristina region, from its neighboring cities during the time. According to the census of 2011, the average residential density in the urban region of Prishtina, is about 300 inhabitants / km2 (See fig.x.), But it manages and number over 5000 ban $/ \mathrm{km} 2$, in close strict urban center.

According to internal migration map of Kosovo, at the country level for the urban region of Pristina, have the highest level of arrivals in the region, the above 100. According to the maps shown below, the most rregular traveling to Prishtina city are from the neighboring cities, more than 1000 people/day. The distance of traveling is shown in the next map distance from $21-60 \mathrm{~km}$.

\footnotetext{
58

${ }^{59}$ FUA - "Functional Urban Zone, ("Redefining urban", Department for Communities and Local Government, United Kingdom, 2012);
} 


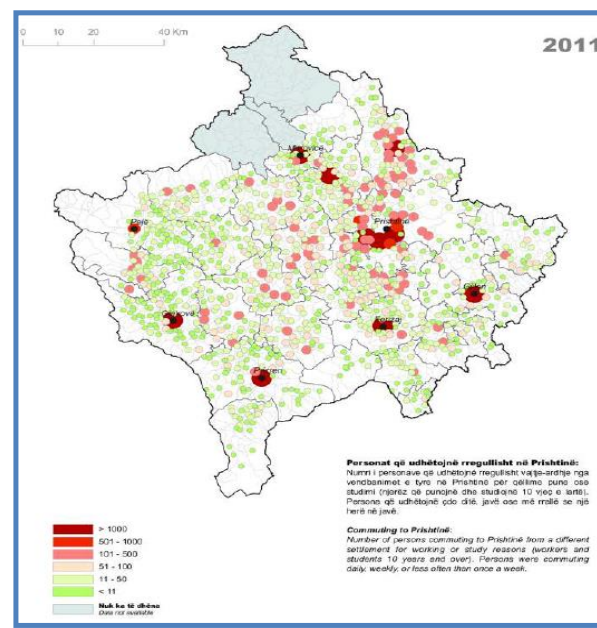

Fig.4. Persons who travel regularly

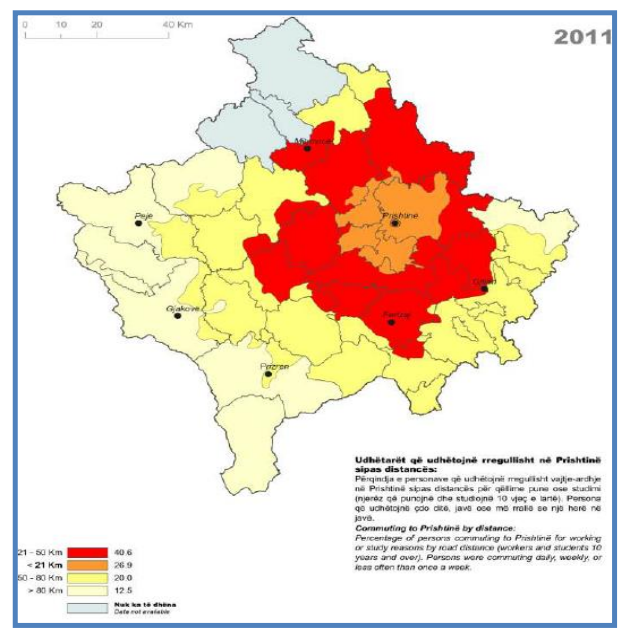

Fig.5.. Persons who travel regularly in Pristina (ESK, 2011)

According to the OECD definition, Pristina, with about 200,000 inhabitants in its municipality and 148,000 in its urban area represents $74 \%$ of the urban population. According to the OECD definitions - City of Pristina could be categorized as a city - Urban Hub of medium size with 200 000 inhabitants (without area of four neighboring municipalities), as would also be of medium size with cca 406,000 urban residents (with four neighboring municipalities).

Identification of the Daily Migration Zone of the Region according to the OECD, is done through argumentation criteria that over $15 \%$ of daily workers comes from another neighboring urban area, while working in another urban center. Based on this criterion, in the case of Pristina there is as per latest statistics of census 2011, according to the Statistical Office of Kosovo, daily arrivals of workers in Pristina over 35\%. This is the level of daily migration, which comes from neighboring municipalities: (Lipljan, Fushe Kosove, Kastriot and Podujeve), to the the urban center of Pristina which has over 50,000 inhabitants.

\section{Conclusions and reccomendations}

\section{1. - Could be Prishtina defined as Functional Urban Zone/Metropolitan Urban Region?}

Prishtina could be defined as Metropolitan Urban Region according to existing potentials, role and functions with the neighboring cities, due to the the trend of managing the infrsatrcuture reisurces in daily basis, that are physicaly in three other cities around: Intl Airport of Prishtina, Main Train Station and Powerplant. If being organised as MUR of Prishtina, urban rural linkages would be stregthened as well, though the main adute to knowledge based developemnd of Prishtina as accessibility would be achieved, though the economic base of the region woud be strengthened and reinforced, being more attractive to MNC- multinational companies and other that needs other supporting national policies. Social inclusiveness, better public transport, though competitiveness would be the main keywords.

\section{According to the future plans and scenarios for its spatial development?}

Prishtina could be defined as Metropolitan Urban Region according to national strategic spatial planning documents, hence has big support in this respect that reccomends regionalisation, i.e. so 
called BLUE PORT. (SPK Spatial Plan of Kosova 2010 - 2025+). It is needed joint spatial development planning, i.e. regional planning that could be delt from an Regional Planning Agency, that would manage regional issues, strengthen synergies and avoid challenges, by functioning as one Metropolitan urban region

It is reccomended the redefinition of local plans, in order to be in line with the main objective to development as region of the Prishtina Metropolitan.

3. According to the indicator of daily migration as per OECD criterias?

Prishtina could be defined as Metropolitan Urban Region, according to the daily migration of 35 $\%$ from its region as per recent statistical data. By this indicator is reinforced and concluded the need for regionalisation, putting into action in the aspect of commuting policies, environmental sustainable transport planning, that would support the daily migration to and from Prishtina city. Policy and planning implications to the aim of being Metropolitan Urban Region of Prishtina would be: Joint spatial development planning; Joint Development management and monitoring; Institutional Development for new creation of new reality of regionalisation; start up of creation of NUTS system in Kosovo.

\section{References}

1. De Roo G., and Miller D., 2000, “Compact Cities and Sustainable Urban Development”: A Critical Assessment of Policies and Plans from an International Perspective, Ashgate, Aldershot;

2. Docherty I., and Shaw I., 2003,"A New Deal for Transport? The UK's Struggle with the Sustainable Transport Agenda", Blackwell Publishing, Oxford.

3. EC for Communities,2009, "Action Plan on Urban Mobility", Brussels;

4. ESPON \& Vienna University of Technology, 2012., POLYCE Metropolisation and Polycentric Development in Central Europe.

5. ESPON, 2012, Final Report, POLYCE 'Metropolisation and Polycentric Development in Central Europe', URL:http://www.espon.eu/export/sites/default/Documents/Projects/TargetedAnalyses/POL YCE/FR/POLYCE_FINAL_MAINREPORT.pdf (30.01.2015).

6. European Smart Cities: the need for a place related Understanding, Department of Spatial Development, Infrastructure and Environmental Planning Centre of Regional Science, http://www.srf.tuwien.ac.at/, Edinburgh Napier University, 2011

7. Feitelson E., and Verhoef E., 2001, "Transport and Environment: In Search of Sustainable Solutions, Edward Elgar Publishing Ltd, London;

8. Gribben, A., 2003, "Certifying vocational skills in Kosovo: establishing first institutions", European Training Foundation, -Prishtina;

9. Institute for Advanced Studies GAP Pristina.,2009, "Municipal Report" ; Prishtina;

10. Ministry of Infrastructure, 2012, “ Strategic document for Multinodal transport 2012-2021 and Action Plan 2012-2016", Prishtina;

11. Municipality of Prishtina, 2004, "Strategic urban development plan of Prishtina - Prishtina $2020+$ +", Prishtina.

12. Newman P.W.G., and Kenworthy J.R., 1989, "Cities and Automobile Dependence". An International Sourcebook, Gower;

13. Nicolas J.-P., Poimboeuf P., "Towards Sustainable Mobility Indicators-Application to the Lyons conurbation", Laboratoire d'Economie des Transports, Lyon- France. 
Book of Proceedings

International Conference on Architecture and Spatial Planning

14. OECD (Organisation for Economic Co-operation and Development), 2002, "Policy Instruments for Achieving Sustainable Transport, OECD, http://www.oecd.org ;

15. Pei L., 2011, "Behaviors on Intra-urban Residential Mobility: ARevieë and Implications to the Future Research", Institute of Real Estate Studies, National University of Singapore, Singapore

16. Regional Development Programme of the Ljubljana Urban Region 2007 - 2013, 2007. Regional Development Agency of the Ljubljana Urban Region. URL:

http://www.rralur.si/fileadmin/user_upload/razvojni_dokumenti/prevedeni_RRP_LUR_20_ 04_07_1_10_07.pdf (30.01.2015). 